\title{
THE EFFECT OF THE OESTROUS CYCLE, PREGNANCY AND REPRODUCTIVE HORMONES ON THE KININASE ACTIVITY OF RAT BLOOD
}

\author{
J. T. McCORMICK AND JUDITH SENIOR \\ Postgraduate School of Studies in Pharmacology, \\ University of Bradford, Bradford 7
}

(Received 19th Fuly 1971, accepted 5th November 1971)

\begin{abstract}
Summary. The kininase activity of female rat blood was found not to change during the oestrous cycle. In pregnant rats, the kininase levels were found to decrease significantly with advancing gestation, reaching the lowest level around Day 20 of pregnancy. There was a rise towards normal levels in lactating rats but the normal non-pregnant level had not been attained by Day 14 of the puerperium.

The maternal blood volume was shown to increase with advancing gestation until Day 20, when it levelled out.

Administration of oestrogens to non-pregnant rats caused a decrease in kininase activity whereas progestagens did not have a significant effect.
\end{abstract}

\section{INTRODUCTION}

In the circulating blood, red blood cells, leucocytes, thrombocytes and plasma contain active kininases. One of the characteristics of bradykinin is the rapid inactivation of the peptide in normal plasma. This homeostatic mechanism is a major factor in determining the duration of action of bradykinin (Erdos \& Yang, 1970).

There is evidence in favour of an active participation of kinin during birth and in the puerperium. Armstrong \& Stewart (1960) observed a spontaneous release of kinins with subsequent decrease of kininogen in plasma taken from women during labour. Martinez, Carvalho \& Diniz (1962) described a discrete fall in bradykininogen content of the blood of women during labour.

However, experiments in which kininase activity was measured in plasma of pregnant women yielded controversial results. Effkemann \& Werle (1941) and Armstrong \& Stewart (1960) did not observe any increase in the blood enzyme level while Centaro, Periti \& Sicuteri (1963) and Werle (1960) noticed that blood, serum or plasma taken from pregnant women destroys kinins faster than does normal blood.

This paper describes experiments to investigate the kininase activity of rat blood during the oestrous cycle, pregnancy, parturition and lactation. The effect of sex hormones on the kininase activity of blood for non-pregnant rats was also studied. 


\section{MATERIALS AND METHODS}

Mature female albino rats of the CSE strain, weighing 200 to $250 \mathrm{~g}$, were used. The animals were allowed free access to food and water.

Vaginal smears were taken daily from non-pregnant rats and the day of the oestrous cycle was designated according to the criteria of Long \& Evans (1922).

For the experiments involving pregnant animals, female rats were housed six to a cage with a male rat. Vaginal smears were taken daily and the 1st day of pregnancy was defined as the day on which spermatozoa were first found in the vagina.

Parturition occurred on the night of Day 22 or in the early morning of Day 23. Day 23 was designated Day 1 of lactation and the number of young per litter for each lactating rat was adjusted to eight.

\section{Injection of sex hormones}

Stilboestrol, oestradiol benzoate, ethinyl oestradiol and progesterone were dissolved in $0 \cdot 1 \mathrm{ml}$ arachis oil and were injected daily for 5 days into groups of non-pregnant animals. Control groups of animals were injected with $0.1 \mathrm{ml}$ arachis oil/animal/day.

Similar experiments were performed with oestrone hemisulphate dissolved in $0.1 \mathrm{ml}$ distilled water and norgestrel suspended in $0.1 \mathrm{ml}$ distilled water. Control groups were injected with $0.1 \mathrm{ml}$ distilled water. All injections were given by the subcutaneous route.

On Day 6, the animals were killed and the kininase activity of the blood was determined.

\section{Kininase activity}

The kininase activity of rat blood was determined using a method similar to that of Abe, Naoya, Naofumi, Isao, Koichi, Toshikatsu, Atsushi \& Kaoru (1965). All syringes and glassware coming into contact with either blood or bradykinin were coated with a $5 \%$ solution of silicone concentrate (Silicad, Clay Adams, New York).

A preliminary experiment was performed. Different volumes of blood were taken by cardiac puncture from normal female rats anaesthetized with diethyl ether. These blood samples were made up to $1 \mathrm{ml}$ with normal saline and preincubated for $5 \mathrm{~min}$ at $37^{\circ} \mathrm{C}$. To each sample was added $1 \mathrm{ml}$ synthetic bradykinin $(1 \mu \mathrm{g} / \mathrm{ml})$ in normal saline, which had also been preincubated at $37^{\circ} \mathrm{C}$ for $5 \mathrm{~min}$. The mixtures were incubated for $10 \mathrm{~min}$ at $37^{\circ} \mathrm{C}$ and the reaction was terminated by plunging the samples into an ice-water cooling mixture at $0^{\circ} \mathrm{C}$. The remaining bradykinin was assayed on a segment of isolated guineapig ileum suspended in aerated Tyrode solution at $32^{\circ} \mathrm{C}$. The Tyrode solution contained atropine sulphate $10^{-6} \mathrm{~g} / \mathrm{ml}$, diphenhydramine hydrochloride $10^{-6} \mathrm{~g} / \mathrm{ml}$ and bromolysergic acid diethylamide $5 \times 10^{-7} \mathrm{~g} / \mathrm{ml}$.

The kininase activity was expressed as the percentage destruction of the bradykinin under the standard conditions mentioned above. A graph was composed of percentage destruction of bradykinin against plasma volume and the volume of plasma corresponding to approximately $50 \%$ destruction of the 
bradykinin was used as the standard volume of plasma in the following experiments.

\section{Measurement of the maternal blood volume}

The maternal blood volume was measured using the method of Robson \& Senior (1964).

\section{RESULTS}

The destruction of bradykinin was seen to show a linear relationship with the logarithmic concentration of the blood (Text-fig. 1). Approximately 50\%

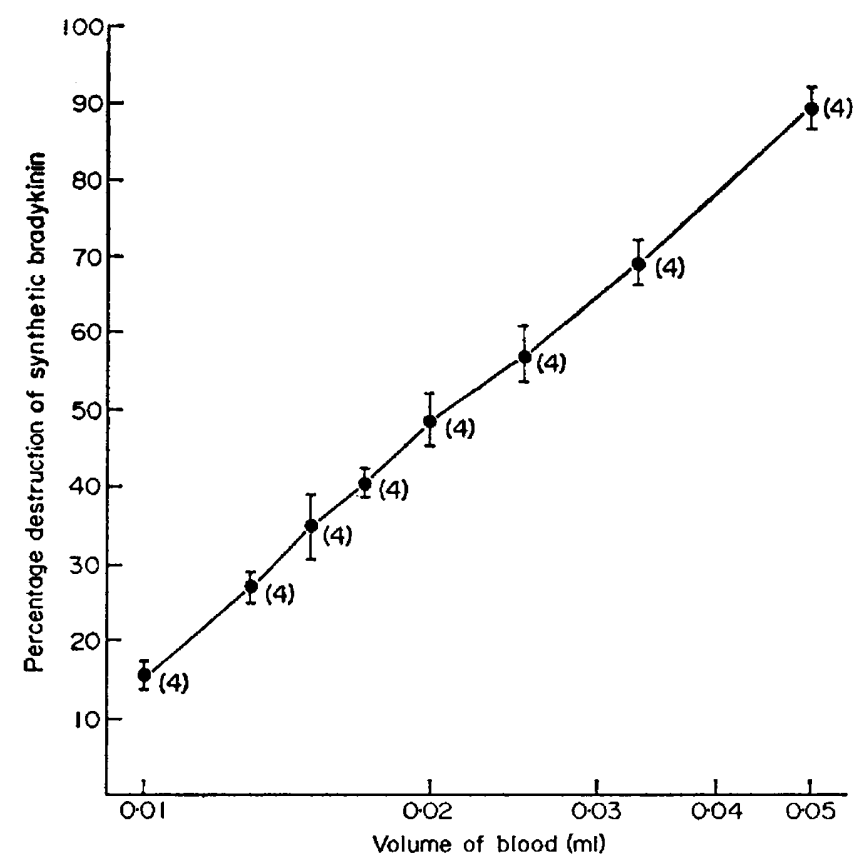

TExT-FIG. 1. The effect of female rat blood upon the destruction of $1 \mathrm{ml}$ synthetic bradykinin $(1 \mu \mathrm{g} / \mathrm{ml})$. Numbers within parentheses indicate the number of observations. Standard errors are indicated.

destruction of the synthetic bradykinin was achieved using a volume of $0.02 \mathrm{ml}$ blood. This volume of blood was used in the following experiments.

Kininase activity during the oestrous cycle and pregnancy

The kininase activity of rat blood was found to be constant throughout the oestrous cycle. These results are shown in Table 1.

In pregnant rats, the blood kininase activity was markedly depressed as gestation advanced (Text-fig. 2), the lowest value being obtained around Day 20. There was a significant fall in kininase levels between Day 15 and Day 20 of gestation $(P=0.01)$. Between Days 20 and 21 of gestation, there was a significant rise in kininase levels $(P=0.01)$, this new level being maintained until Days 2 to 3 post partum. Between Days 2 to 3 post partum and Days 4 to 5 post 
TABLE 1

THE KININASE AGTIVITY OF FEMALE RAT BLOOD DURING THE OESTROUS CYGLE.

\begin{tabular}{l|c|c}
\hline $\begin{array}{c}\text { Stage of oestrous } \\
\text { cycle }\end{array}$ & $\begin{array}{c}\text { Mean percentage destruction } \\
\text { of synthetic bradykinin } \\
\text { (No. of observations) }\end{array}$ & $\begin{array}{c}\text { Standard } \\
\text { error }\end{array}$ \\
\hline Pro-oestrous & $50 \cdot 9(6)$ & $2 \cdot 047$ \\
Oestrous & $49 \cdot 3(6)$ & $1 \cdot 646$ \\
Dioestrous & $51 \cdot 3(7)$ & $2 \cdot 078$ \\
\hline
\end{tabular}

partum, the level of kininase again rose significantly $(P=0.05)$ and this new level was maintained until at least Day 14 post partum. This level at Day 14 post partum was still significantly lower $(P=0.05)$ than the level of kininase activity in the blood of normal non-pregnant rats.

\section{Maternal blood volume during pregnancy}

Text-fig. 3 shows the maternal blood volume of rats during pregnancy and early puerperium. The maternal blood volume increased steadily to Day 18 of pregnancy. There was a rapid rise in the blood volume from Day 18 to Day 20 of gestation and this was maintained to Day 22. Following parturition, the maternal blood volume returned to non-pregnant values.

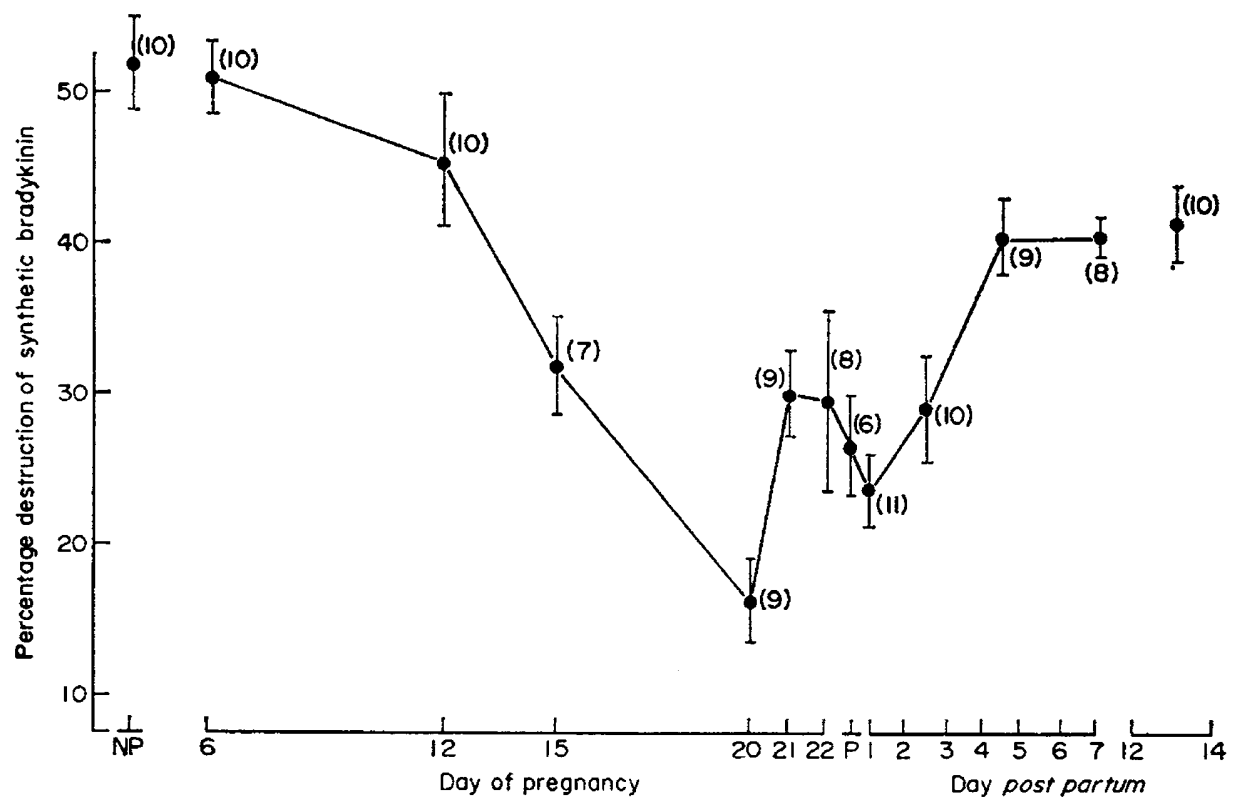

TEXT-FIG. 2. The kininase activity of rat blood during pregnancy, parturition, and puerperium. NP $=$ non-pregnant rats; $P=$ parturition. Numbers within parentheses indicate the number of observations. Standard errors are indicated. 
Effect of oestrogens and progestagens on kininase levels

The effect of oestrogens and progestagens on kininase levels in the blood of non-pregnant intact rats is shown in Text-fig. 4. Administration of stilboestrol $(50 \mu \mathrm{g} / \mathrm{kg}$ and $100 \mu \mathrm{g} / \mathrm{kg})$, oestradiol benzoate $(10 \mu \mathrm{g} / \mathrm{kg}$ and $20 \mu \mathrm{g} / \mathrm{kg})$ and ethinyl oestradiol $(20 \mu \mathrm{g} / \mathrm{kg})$ daily for 5 days produced significant decreases $(P=0.05)$ in kininase activity in the rat blood. Oestrone hemisulphate $(25$ $\mu \mathrm{g} / \mathrm{kg}$ and $50 \mu \mathrm{g} / \mathrm{kg})$ and ethinyl oestradiol $(10 \mu \mathrm{g} / \mathrm{kg})$ showed no significant effect. Neither progesterone nor norgestrel in either of the doses used $(500 \mu \mathrm{g} / \mathrm{kg}$ and $1 \mathrm{mg} / \mathrm{kg}$ ) showed any effect on the kininase activity of rat blood.

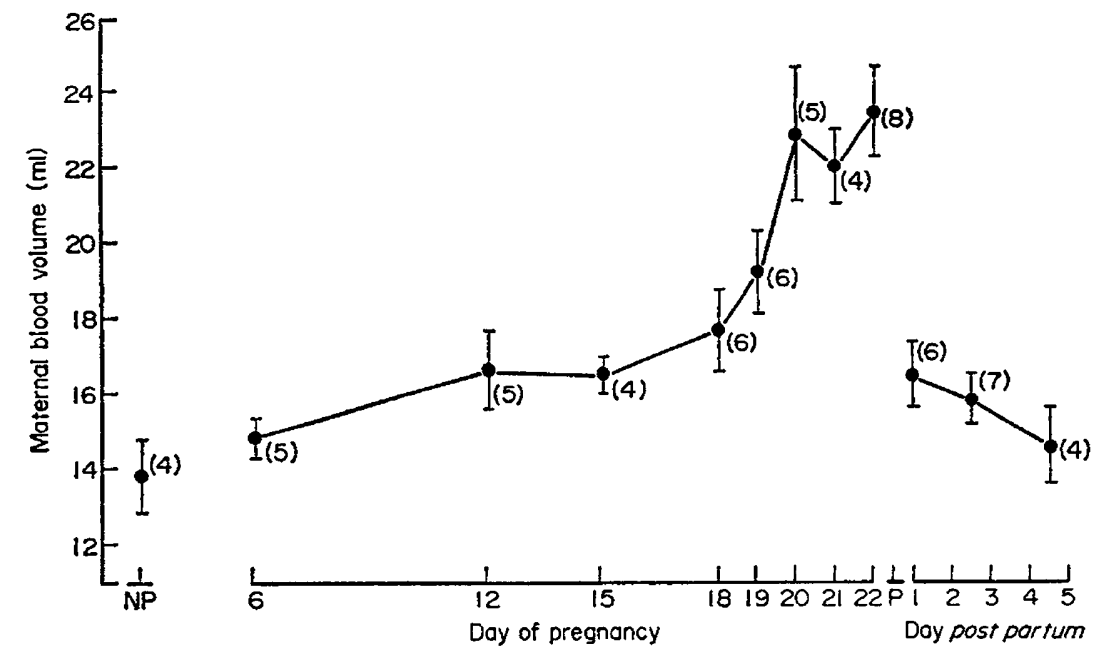

TEXT-Fig. 3. The maternal blood volume of the rat during pregnancy and early puerperium. $\mathrm{NP}=$ non-pregnant rats; $\mathbf{P}=$ parturition. Numbers within parentheses indicate the number of observations. Standard errors are indicated.

\section{DISCUSSION}

These experiments show that there is a large decrease in the kininase activity of the circulating maternal blood during pregnancy in the rat. The lowest levels of kininase activity were around Day 20 of gestation. It can be seen from Text-fig. 1 that the kininase activity on Day 20 of pregnancy would be found in a blood volume of approximately $0.01 \mathrm{ml}$. This activity, therefore, is approximately half that found in the blood of a normal non-pregnant female rat. If this decrease in kininase activity during pregnancy is related to the maternal blood volume (Text-fig. 2), it may be a dilution effect. The maternal blood volume on Day 20 of pregnancy is almost double the volume of blood circulating in a normal nonpregnant female rat; the kininase activity at this time is approximately half the normal level.

After Day 20 of gestation, the maternal blood volume appears to remain constant up to parturition. The kininase activity, however, increases significantly from Day 20 to Day 21 of gestation $(P=0.01)$. This rise in the kininase content 
of the maternal blood may perhaps be related to the changes in hormonal levels which are taking place at this stage of pregnancy.

Investigation into the effects on blood kininase activity of oestrogens and progestagens in non-pregnant rats shows that in the doses used, progestagens do not affect the kininase activity. Oestrogens, however, can achieve a significant depression of the kininase activity of the blood (Text-fig. 4). The rise in kininase activity on Day 21 of pregnancy is, therefore, somewhat unexpected as there is a
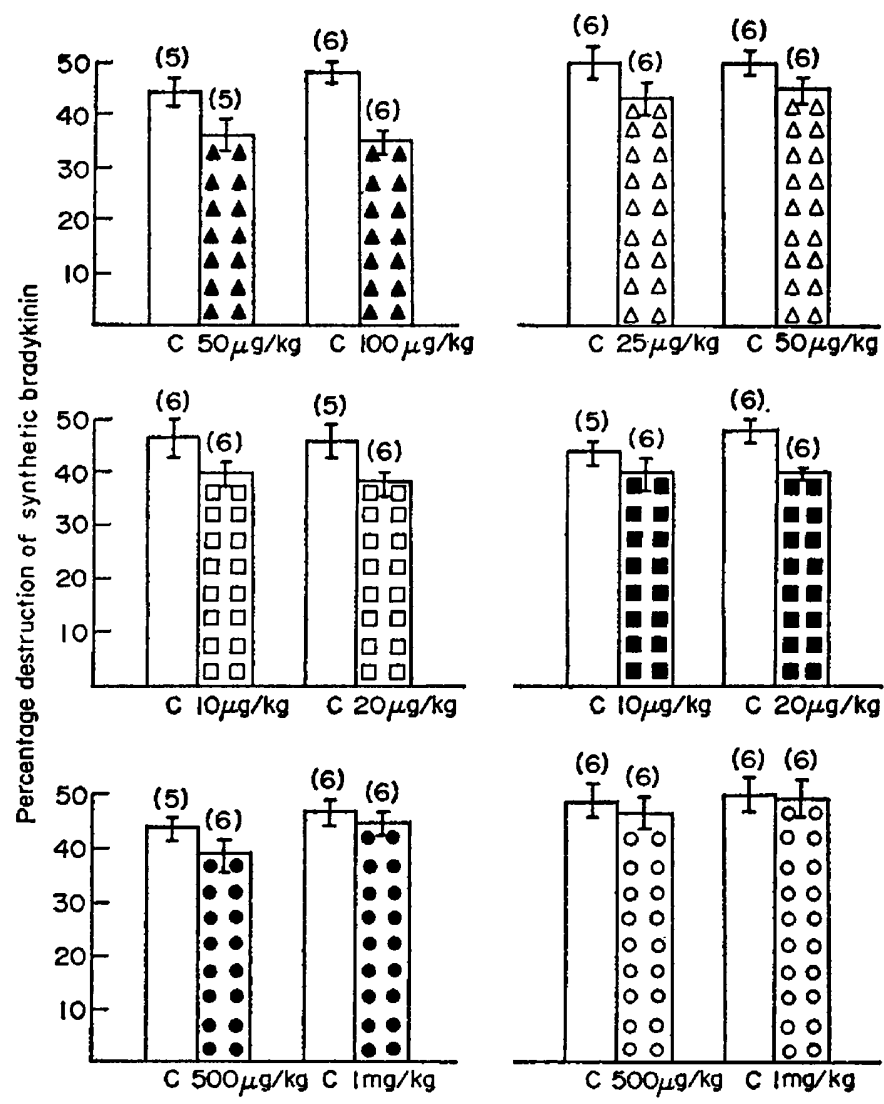

Text-Fig. 4. The effect of oestrogens and progestagens on the kininase activity of the blood of normal, non-pregnant, female rats. $\Delta$, Stilboestrol; $\mathbf{\square}$, ethinyl oestradiol; $\Delta$, oestrone hemisulphate; $\square$, oestradiol benzoate; $\boldsymbol{\theta}$, progesterone; $O$, norgestrel. $\mathrm{C}=$ control groups. Numbers within parentheses indicate the number of observations. Standard errors are indicated.

surge of oestrogen from the rat ovary around Day 20 of gestation (Yoshinaga, Hawkins \& Stocker, 1969). It has been shown that the peripheral plasma progesterone levels in the rat fall around Day 20 of pregnancy (Csapo \& Wiest, 1969) but, as progesterone does not appear to affect the kininase activity in nonpregnant rat blood, the fall in progesterone level seems unlikely to be involved in the increase in kininase activity at this time. It appears, therefore, that the rise in kininase activity, which occurs following Day 20 of pregnancy is not mediated through the changes in the oestrogen and progesterone levels. 
Following parturition in the rat, the blood volume returns to non-pregnant levels within 4 days. At this time, the kininase level has increased significantly from the level found in late pregnancy $(P=0.05)$. This new level of kininase remains stable until at least 14 days post partum, during which time lactation was occurring as the young were allowed to remain with the mother. The level of kininase during lactation is significantly lower than the level found in nonpregnant females; it appears that the process of lactation may in some way lower the blood kininase activity.

The increase in kininase activity in the blood during the last 2 days of pregnancy may mean that the level of free circulating kinin could fall. This could be a protective mechanism so that the blood flow to the uterus and placenta is not diminished by the vasodilator effect of free kinin. Work is in progress to investigate the levels of kininogen, the kinin precursor, in the rat during pregnancy and parturition.

\section{ACKNOWLEDGMENTS}

We should like to thank the Medical Research Council for financial assistance to one of us J.T.M. We are grateful to Sandoz Products Limited for supplying synthetic bradykinin.

\section{REFERENCES}

Abe, K., Naoya, W., Naofumi, K., Isao, M., Koichi, M., Toshikatsu, S., Atsushi, O. \& Kaoru, Y. (1965) Assay of kininase activity in human blood. Tohoku. F. exp. Med. 86, 77.

Armstrong, D. \& Stewart, J. W. (1960) Spontaneous plasma kinin formation in human plasma collected during labour. Nature, Lond. 188, 1193.

Centaro, A., Perit, P. \& Sicuteri, F. (1963) Bradykininogen and bradykininase in blood of women during labour. Settim. med. 51, Suppl. 1, 70.

Csapo, A. I. \& WIEst, W. G. (1969) An examination of the quantitative relationship between progesterone and the maintenance of pregnancy. Endocrinology, 85, 735.

Effkemann, G. \& Werle, E. (1941) Die Korpereigenen uteruswirksamen und kreislaufaktiven Wirkstoffe im Schwangerenorganismus. Arch. Gynaek. 171, 1.

Erdos, E. G. \& YANG, H. Y. T. (1970) Handbook of experimental pharmacology. Bradykinin, kallidin and kallikrein, p. 289. Springer, Berlin.

Long, J. A. \& Evans, H. M. (1922) The oestrous cycle in the rat and its associated phenomena. Mem. Univ. Calif. 6.

Martinez, A. R., Garvalho, I. F. \& Diniz, C. R. (1962) The bradykininogen content of plasma from women in labour. 7. Obstet. Gynaec. Br. Commonw. 69, 104.

Perit, P. \& Gasparri, F. (1966) Hypotensive peptides, p. 536. Springer, Berlin.

Robson, J. M. \& Senior, J. B. (1964) The 5-hydroxytryptamine content of the placenta and foetus during pregnancy in mice. Br. 7. Pharmac. Chemother. 22, 380.

WerLe, E. (1960) Kallikrein, kallidin and related substances. In: Polypeptides which Affect Smooth Muscle Blood Vessels, p. 199. Ed. M. Schachter. Pergamon Press, London.

Yoshinaga, R., Hawkins, R. A. \& Stocker, J. F. (1969) Oestrogen secretion by the rat ovary in vivo during the oestrous cycle and pregnancy. Endocrinology, 85, 103. 